\title{
To Evaluate Maternal Platelet Indices in Preterm Premature Rupture of Membranes and Their Relation with Adverse Neonatal Outcomes
}

Dr. Urmila Kumari ${ }^{1}$, Dr. Kavita Choudhary ${ }^{2}$, Dr. Premlata Mital ${ }^{3 *}$, Dr. Jeetendra Singh ${ }^{4}$, Dr. Ankita Choudhary ${ }^{5}$, Dr. Saloni Sethi ${ }^{6}$, Dr. Aditi Arora ${ }^{7}$, Dr. Vikash Kumari ${ }^{8}$

${ }^{1,2} \mathrm{PG}$ student, ${ }^{3}$ Senior Professor, ${ }^{4-8} \mathrm{PG}$ student, Department of Obstetrics and Gynaecology S.M.S. Medical College, Jaipur India

DOI: $10.36348 /$ sijog.2020.v03i03.008

| Received: 19.03.2020 | Accepted: 26.03.2020 | Published: 27.03.2020

*Corresponding author: Dr. Premlata Mital

\section{Abstract}

Preterm premature rupture of membranes is one of the most common issues in daily obstetrics practice. PPROM is associated with $30 \%$ of neonatal morbidities and mortalities in preterm delivery. Increased PLT consumption causes activation and increased production of PLT, which causes a hypercoagulable state and microcirculatory defects and vascular reactivity in the placental bed, resulting in placental insufficiency and adverse neonatal outcomes. The present study aimed to determine platelet indices in PPROM patients and to evaluate the association between PLT indices and adverse neonatal outcomes. Material and methods: This was a hospital based descriptive study. 130 women with PROM \& 130 women without PROM with gestational age between $24-36.6$ weeks admitted in the labour room for delivery were included in the study. CBC was done for all. Relationship between PLT indices and neonatal outcomes in PPROM cases were analyzed. Results: The mean platelet count in women of study group $\left(224.2 \pm 66.43 \times 10^{3} / \mathrm{mm}^{3}\right)$ was 1 lower than mean platelet count in women of control group $\left(232 \pm 71.58 \times 10^{3} / \mathrm{mm}^{3}\right)$. Mean MPV and PDW were significantly more in study group. There was a weak positive correlation existed between Platelet count and APGAR score and birth weight of the baby. A negative correlation existed between MPV and APGAR and birth weight. Conclusion: Platelet count, MPV and PDW which are simple, economical and rapid to measure, can be used to predict adverse outcome in PPROM.

Keywords: Maternal Platelet Premature Rupture.

Copyright @ 2020: This is an open-access article distributed under the terms of the Creative Commons Attribution license which permits unrestricted use, distribution, and reproduction in any medium for non-commercial use (NonCommercial, or CC-BY-NC) provided the original author and source are credited.

\section{INTRODUCTION}

Preterm premature rupture of membranes (PPROM) is one of the most common and controversial issues in daily obstetrics practice. Premature rupture of membranes (PROM) refers to rupture of foetal membranes prior to the onset of labour and Preterm premature rupture of membranes (PPROM) is defined as spontaneous rupture of foetal membranes prior to 37 weeks of gestation [1]. It affects approximately 3 $4.5 \%$ of all pregnancies [2,3]. PPROM is associated with $30 \%$ of neonatal morbidities and mortalities in preterm delivery [4]. A timely and accurate diagnosis of PPROM is critical to optimize pregnancy outcome. Recent studies have shown that the risk of maternal and neonatal infections increases as the time required until delivery increases $[5,6]$. However, there is no useful predictive biomarker of adverse maternal and neonatal outcomes in PPROM.

Normal pregnancy is characterized by an increase in platelet aggregation and a decrease in the number of circulating platelets with gestation. Platelet lifespan declines and the MPV increases minimally during pregnancy. Increased consumption of platelets in the uteroplacental circulation has been suggested to be the explanation of the reduction in the number of circulating platelets [7]. Platelet (PLT) indices, mean platelet volume (MPV), platelet distribution width (PDW) and plateletcrit (PCT), are determinants of PLT functions, simply assessed by complete blood count $(\mathrm{CBC})$. Currently they are frequently being investigated in a wide variety of clinical conditions. Disturbed PLT functions are implied in hypertension; diabetes; myocardial infarction; cerebrovascular disease; and 
some inflammatory diseases, such as systemic lupus erythematosus, inflammatory bowel disease and rheumatoid arthritis [8]. In addition to these, the association between disturbed PLT indices and obstetric conditions, such as recurrent pregnancy loss, first trimester miscarriage, pre-eclampsia, gestational diabetes and preterm labor, have been investigated[913].

PLT indices could be useful biomarkers in PPROM cases. Increased PLT consumption causes activation and increased production of PLT, which causes a hypercoagulable state and microcirculatory defects and vascular reactivity in the placental bed, resulting in placental insufficiency and adverse neonatal outcomes [10-13]. Till date very few studies have been done to find association of platelet indices with PPROM. The present study aimed to determine platelet indices (PLT count, MPV, PDW and PCT) in PPROM patients and to evaluate the association between PLT indices and adverse neonatal outcomes, such as low birth weight, APGAR scores $<7$ at $5 \mathrm{~min}$, requirement of neonatal intensive care unit (NICU) admission and the development of neonatal sepsis and respiratory distress syndrome (RDS) in PPROM patients.

\section{MATERIAL AND METHODS}

This was a hospital based descriptive study carried out in department of Obstetrics and Gynaecology, S.M.S Medical College and attached groups of hospital, Jaipur. Study population was all pregnant woman admitted in the labour room for delivery with gestational age between $24-36.6$ weeks after applying inclusion and exclusion criteria. Study Group -Women with PROM and Control - Women without PROM.

Sample size was calculated at $80 \%$ study power and error of 0.05 assuming the standard deviation of $2.8 \mathrm{fl}$ in MPV among control group as per result of seed article. For minimum detectable mean difference of $1 \mathrm{fl}$ in MPV, 123 patients in each group are required for this study which is further enhanced and rounded off to 130 patients in each group as final sample size expecting 5\% drop out/attrition.

Inclusion criteria: singleton live pregnancy of gestational age between 24-36.6 weeks and willing to participate in the study

\section{EXCLUSION CRITERIA}

Women with pre-eclampsia, GDM, other medical disorders, IUGR and history of hematopoietic disorders. Institution Review Board \& Ethical committee approval was taken prior to commencement of the study. Detailed clinical history, examination, routine investigations and USG were done for all pregnant women with gestational age between $24-36.6$ weeks, admitted in the labour room. PPROM was confirmed by: history, observation of pooling of amniotic fluid in posterior fornix of vagina or active leakage of amniotic fluid from cervix and fern test if required. $\mathrm{CBC}, \mathrm{C}$ reactive protein other investigations were done. Labor was induced in pregnancies complicated with PPROM at and after 34 weeks of gestation. Betamethasone was given for lung maturation to all women. All women were monitored throughout labour and delivery outcomes were noted. Birth weights of neonates, 5 min APGAR score, development of neonatal sepsis, development of neonatal RDS and NICU admission were noted. Data were entered into MS excel sheets and statistically analyzed to find any alterations in PLT indices between the PPROM group and control. We looked for a relationship between PLT indices and neonatal outcomes in PPROM cases.

\section{RESULTS}

Socio-demographic profile of the women is shown in Table 1. Majority of the women in study group $(63.8 \%)$ and control group $(73 \%)$ were below 25 years. The mean age of women in study group and control group was 23.5 \pm 2.36 years and 22.5 \pm 2.1 years respectively. Most of women belonged to rural areas (study group-60.8\% and control group 73.8\%). 53.1\% women in study group were non-booked as compared to control group and the difference between two groups was statistically significant ( $\mathrm{p}$ value 0.04 ) at $\mathrm{p}<0.05$. Majority of women in both groups were Hindu, literate, belonged to middle socio-economic status according to modified B G Prasad Classification, and had normal $\mathrm{BMI}$ and primigravida.

In both study and control group, majority of the women were having gestational age more than 32 weeks and below 36.6 weeks (90.8\% in study and $86.2 \%$ in control group). Extreme prematurity was seen in $1.5 \%$ study as well as in control group. Both the groups were comparable with no significant difference (p value 0.5 ) (Table 2).

Neonatal outcome is shown in Table 3. NICU admission, RDS and septicemia were significantly more in babies born to women with PPROM than without PPROM.

Table 4 shows CBC parameters. Women with PPROM had slightly more WBC counts than without PPROM (10.92 \pm 3.77 vs 10.26 \pm 4.36$)$. Similarly neutrophilic count was slightly more in women with PPROM than in women without PPROM $(8.79 \pm 3.77$ vs $7.92 \pm 4.31)$. The difference in WBC count and neutrophil count was statistically not significant. PPROM was also associated with abnormal erythrocyte parameters including anaemia. Mean RDW in study group was $19.89 \pm 10.61 \%$ and in control group was $15.7 \pm 2.74 \%$. RDW was significantly more in study group ( $\mathrm{p}=0.0000)$ The mean platelet count in women of study group $\left(224.2 \pm 66.43 \times 10^{3} / \mathrm{mm}^{3}\right)$ was lower than mean platelet count in women of control group 
Urmila Kumari et al; Sch Int J Obstet Gynec, March. 2020; 3(3): 98-105

$\left(232 \pm 71.58 \times 10^{3} / \mathrm{mm}^{3}\right)$. Mean MPV was significantly more in study group $(11.65 \pm 1.04 \mathrm{fl})$ than in control group $(9.98 \pm 0.76 \mathrm{fl})(\mathrm{p}=0.0000)$. The mean platelet distribution width (PDW) in women of study group was $16.04 \pm 3.12 \%$ and in control group it was $14.69 \pm$ $3.08 \%$. The difference in the PDW was statistically significant $(\mathrm{p}=0.0005)$. The mean plateletcrit (PCT) in women of study group was $0.232 \pm 0.048 \%$ and in control group it was $0.207 \pm 0.40 \%$. The difference in the PCT was statistically not significant $(\mathrm{p}=0.4)$.

Correlation between platelet indices and APGAR score and birth weight are shown in Graph 1 to
8. On Pearson's linear regression analysis, there was a weak positive correlation existed between Platelet count and APGAR score $(\mathrm{R}=0.105)$, and birth weight of the baby $(\mathrm{R}=0.014)$. The relation was statistically not significant. On Pearson's linear regression analysis, there was a weak negative correlation existed between PDW and APGAR score ( $\mathrm{R}=-0.126)$, and birth weight of the baby $(\mathrm{R}=-0.142)$, between MPV and APGAR score $(R=0.063)$, and birth weight of the baby $(R=-$ 0.089). There was also a weak negative correlation between PCT and APGAR score $(\mathrm{R}=-0.044)$, and birth weight of the baby $(\mathrm{R}=-0.075)$.

Table-1: Socio-demographic profile of the women

\begin{tabular}{|c|c|c|c|c|c|}
\hline \multirow[t]{2}{*}{ Variables } & \multicolumn{2}{|c|}{$\begin{array}{c}\text { Study group } \\
\quad(\mathbf{n}=\mathbf{1 3 0})\end{array}$} & \multicolumn{2}{|r|}{$\begin{array}{c}\text { Control } \\
(\mathbf{n}=\mathbf{1 3 0})\end{array}$} & \multirow[t]{2}{*}{ P value } \\
\hline & No. & $\%$ & No. & & \\
\hline $\begin{array}{l}\text { Age } \\
<25 \\
>25\end{array}$ & $\begin{array}{l}83 \\
47\end{array}$ & $\begin{array}{l}63.8 \\
36.2\end{array}$ & $\begin{array}{l}95 \\
35\end{array}$ & $\begin{array}{l}73.0 \\
27.0\end{array}$ & $\begin{array}{l}\mathrm{P}=0.1 \\
\text { Not significant }\end{array}$ \\
\hline Mean Age & & $5 \pm 2.36$ & & $22.5 \pm 2.1$ & \\
\hline $\begin{array}{l}\text { Residence } \\
\text { Urban } \\
\text { Rural }\end{array}$ & $\begin{array}{l}51 \\
79\end{array}$ & $\begin{array}{l}39.2 \\
60.8\end{array}$ & & $\begin{array}{l}26.2 \\
73.8\end{array}$ & $\begin{array}{l}\mathrm{P}=0.3 \\
\text { Not significant }\end{array}$ \\
\hline $\begin{array}{l}\text { Religion } \\
\text { Hindu } \\
\text { Muslim }\end{array}$ & $\begin{array}{l}104 \\
26\end{array}$ & $\begin{array}{l}80.0 \\
20.0\end{array}$ & $\begin{array}{l}112 \\
18\end{array}$ & $\begin{array}{l}86.2 \\
13.8\end{array}$ & $\begin{array}{l}\mathrm{P}=0.1 \\
\text { Not significant }\end{array}$ \\
\hline $\begin{array}{l}\text { Literacy status } \\
\text { Literate } \\
\text { Illiterate }\end{array}$ & $\begin{array}{l}81 \\
49\end{array}$ & $\begin{array}{l}62.3 \\
37.7\end{array}$ & & $\begin{array}{c}71.5 \\
28.5\end{array}$ & $\begin{array}{l}\mathrm{P}=0.1 \\
\text { Not significant }\end{array}$ \\
\hline $\begin{array}{l}\text { Socio-economic status } \\
\text { Low } \\
\text { Middle } \\
\text { upper }\end{array}$ & $\begin{array}{l}30 \\
91 \\
9\end{array}$ & $\begin{array}{r}23.1 \\
70.1 \\
6.8\end{array}$ & $\begin{array}{l}41 \\
78 \\
11\end{array}$ & $\begin{array}{r}31.5 \\
60.0 \\
8.5\end{array}$ & $\begin{array}{l}P=0.2 \\
\text { Not significant }\end{array}$ \\
\hline $\begin{array}{l}\text { BMI }(\mathrm{Kg} / \mathbf{m} 2) \\
<18.5 \\
18.5-24.9 \\
25-29.9 \\
>29.9\end{array}$ & $\begin{array}{l}3 \\
102 \\
20 \\
5\end{array}$ & $\begin{array}{r}2.3 \\
78.5 \\
15.4 \\
3.8\end{array}$ & $\begin{array}{l}2 \\
90 \\
26 \\
12\end{array}$ & $\begin{array}{r}1.5 \\
69.3 \\
20.0 \\
9.2\end{array}$ & $\begin{array}{l}P=0.2 \\
\text { Not significant }\end{array}$ \\
\hline $\begin{array}{l}\text { Gravida } \\
\text { Gravida } 1 \\
\text { Gravida } \geq 2\end{array}$ & $\begin{array}{l}73 \\
57\end{array}$ & $\begin{array}{l}56.2 \\
43.8\end{array}$ & & $\begin{array}{l}62.3 \\
37.7\end{array}$ & $\begin{array}{l}P=0.2 \\
\text { Not significant }\end{array}$ \\
\hline
\end{tabular}

Table-2: Distribution according to gestational age

\begin{tabular}{|c|c|c|c|c|c|c|c|}
\hline \multirow[t]{2}{*}{ G A (weeks) } & \multicolumn{2}{|c|}{ Study group } & \multicolumn{2}{|c|}{ Control } & \multicolumn{2}{|c|}{ Total } & \multirow{2}{*}{$\begin{array}{l}\text { Chi-square } \\
\text { P value }\end{array}$} \\
\hline & No & $\%$ & No & $\%$ & No & $\%$ & \\
\hline $24-28$ & 2 & 1.5 & 2 & 1.5 & 4 & 1.5 & \multirow{5}{*}{$\begin{array}{l}X^{2}-2.01 \\
P-.5 \\
\text { Not significant }\end{array}$} \\
\hline $28-32$ & 10 & 7.7 & 16 & 12.3 & 26 & 10.0 & \\
\hline $32-36$ & 93 & 71.5 & 84 & 64.6 & 177 & 68.1 & \\
\hline $36-36.6$ & 25 & 19.3 & 28 & 21.6 & 53 & 20.4 & \\
\hline Total & 130 & 100 & 130 & 100 & 260 & 100 & \\
\hline
\end{tabular}


Table-3: Neonatal outcomes in the study and control groups

\begin{tabular}{|l|l|l|l|l|l|}
\hline \multirow{2}{*}{ Neonatal outcomes } & \multicolumn{2}{l|}{ Study group } & \multicolumn{2}{l|}{ Control } & \multirow{2}{*}{ P value } \\
\cline { 2 - 5 } & No. & $\%$ & No. & $\%$ & \\
\hline Birth weight & & & & & \\
$<1.5$ & 32 & 24.6 & 33 & 25.4 & 0.8, not significant \\
$\geq 1.5$ & 98 & 75.4 & 97 & 74.6 & \\
\hline APGAR <7 (5 min) & 77 & 59.1 & 75 & 57.7 & 0.2, not significant \\
\hline NICU admission & 84 & 64.6 & 63 & 48.5 & $<0.05$, significant \\
\hline RDS & 11 & 13.1 & 3 & 4.8 & 0.04, significant \\
\hline Septicemia & 21 & 25.0 & 10 & 15.9 & 0.03, significant \\
\hline Convulsions & 4 & 4.8 & 5 & 7.9 & 0.7, not significant \\
\hline IVH & 3 & 3.6 & 2 & 3.2 & 0.6, not significant \\
\hline Hypoglycemia & 7 & 8.3 & 6 & 9.5 & 0.7, not significant \\
\hline Hypothermia & 5 & 5.9 & 3 & 4.7 & 0.4, not significant \\
\hline Jaundice & 15 & 17.9 & 12 & 19.0 & 0.5, not significant \\
\hline
\end{tabular}

Table-4: CBC parameters in the study and control groups

\begin{tabular}{|l|l|l|l|}
\hline CBC Parameters & Study Group $(\mathbf{n}=130)$ & Control $(\mathbf{n}=\mathbf{1 3 0})$ & P value \\
\hline $\mathrm{WBC}\left(\mathrm{x} 10^{3} / \mathrm{mm}^{2}\right)$ & $10.92 \pm 3.77$ & $10.26 \pm 4.36$ & 0.19 \\
\hline $\mathrm{Neu}\left(\mathrm{x} 10^{3} / \mathrm{mm}^{2}\right)$ & $8.79 \pm 3.77$ & $7.92 \pm 4.31$ & 0.08 \\
\hline $\mathrm{Hgb}(\mathrm{g} / \mathrm{dl})$ & $10.78 \pm 1.69$ & $11.09 \pm 1.72$ & 0.14 \\
\hline $\mathrm{Hct}(\%)$ & $33.19 \pm 4.56$ & $33.98 \pm 4.60$ & 0.16 \\
\hline RDW $(\%)$ & $19.89 \pm 10.61$ & $15.7 \pm 2.74$ & 0.0000 \\
\hline $\mathrm{Plt}\left(\mathrm{x} 10^{3} / \mathrm{mm}^{3}\right)$ & $224.2 \pm 66.43$ & $232 \pm 71.58$ & 0.3 \\
\hline MPV $(\mathrm{fl})$ & $11.65 \pm 1.04$ & $9.98 \pm 0.76$ & 0.0000 \\
\hline PDW $(\%)$ & $16.04 \pm 3.12$ & $14.69 \pm 3.08$ & 0.0005 \\
\hline PCT $(\%)$ & $0.232 \pm 0.048$ & $0.207 \pm 0.40$ & 0.4 \\
\hline
\end{tabular}

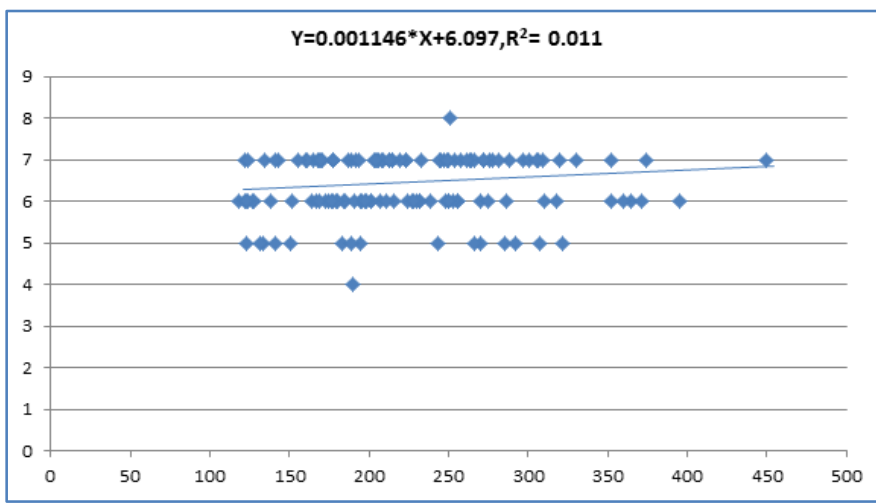

Graph-1: Correlation between platelet count and Apgar score of the babies in PPROM (X axis-PIt, $Y$ axis- Apgar score)

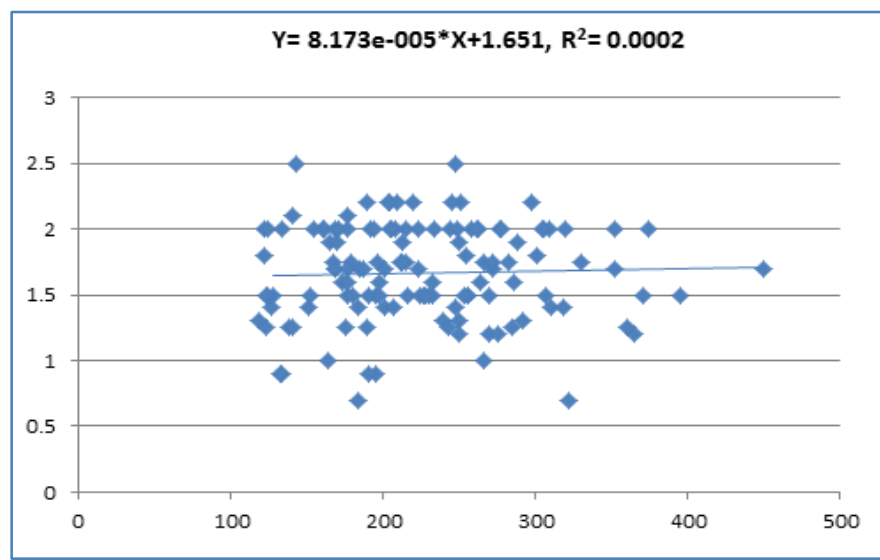

Graph- 2: Correlation between platelet count and birth wt of the babies in PPROM (X axis-PIt, $\mathrm{Y}$ axis-Birth wt) 


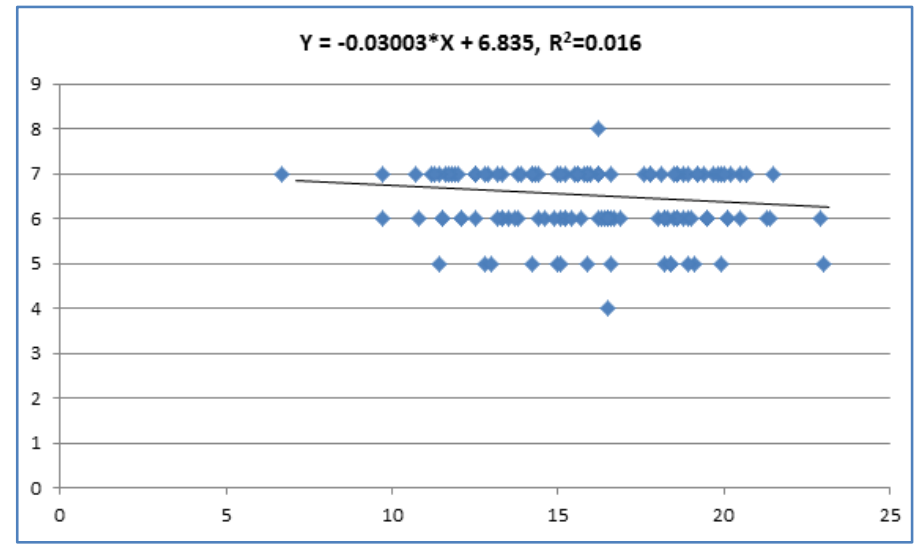

Graph 3: Correlation between maternal PDW and APGAR score of the babies in PPROM (X axis - PDW, Y axis - APGAR score)

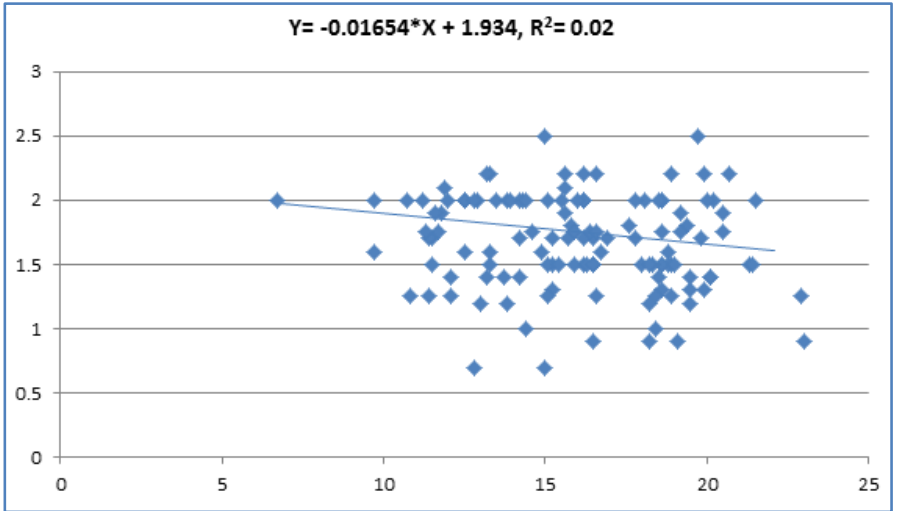

Graph-4: Correlation between maternal PDW and Birth weight of the babies in PPROM (X axis PDW, Y axis Birth Wt)

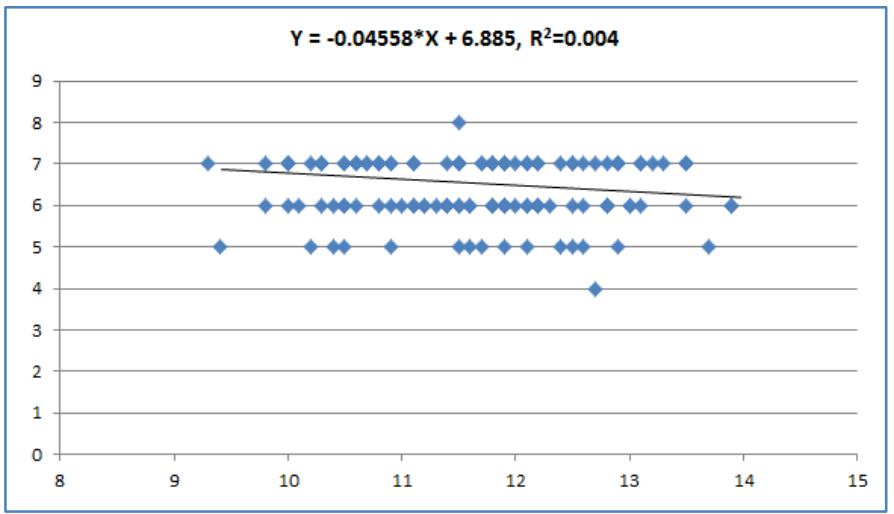

Graph 5: Correlation between maternal MPV and APGAR score of the babies in PPROM (X axis - MPV, Y axis - APGAR score)

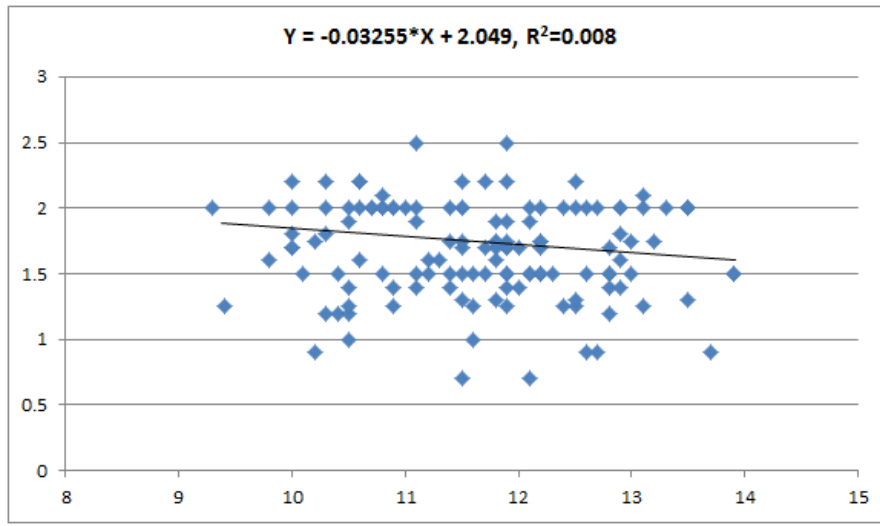

Graph-6: Correlation between maternal MPV and Birth weight of the babies in PPROM (X axis - MPV, $\mathrm{Y}$ axis - birth wt) 


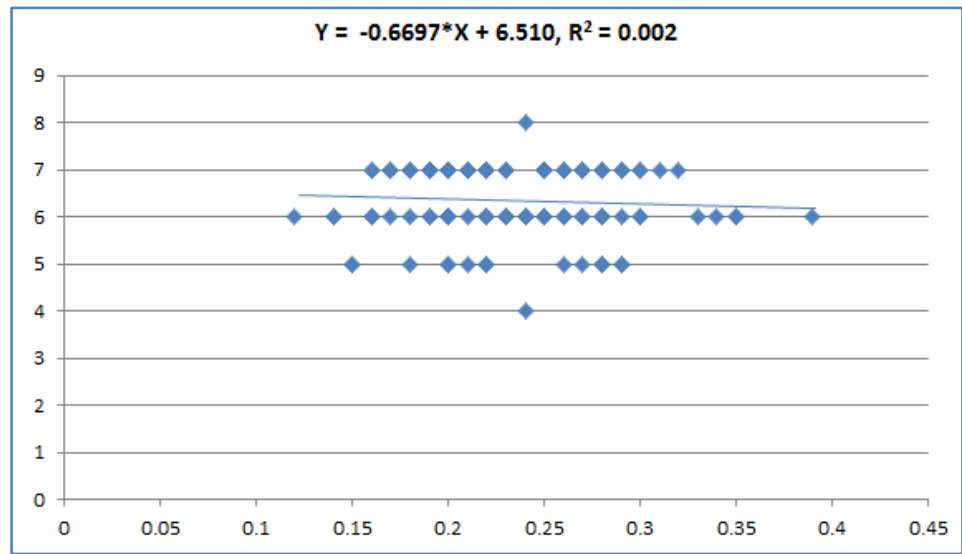

Graph 7: Correlation between maternal PCT and APGAR score of the babies in PPROM (X axis - PCT, Y axis - APGAR score)

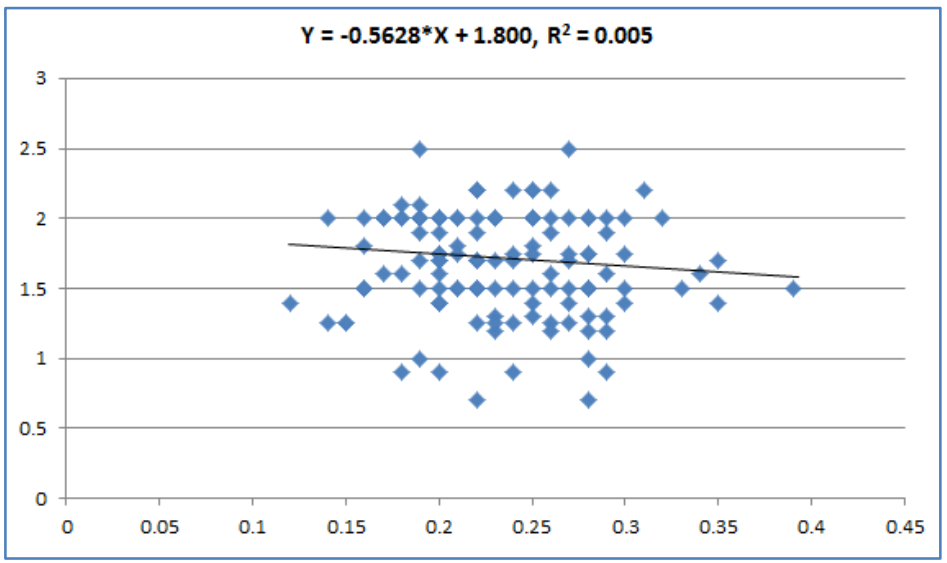

Graph-8: Correlation between maternal PCT and birth weight of the babies in PPROM (X axis - PCT, Y axis - birth wt)

\section{DISCUSSION}

Disturbed platelet functions have been associated with various obstetrics conditions such as recurrent pregnancy loss, first trimester abortion, preeclampsia and preterm labour. So, keeping this in mind the present study was done to evaluate platelet indices (platelet count, mean platelet volume and platelet distribution width) in women with preterm premature rupture of membranes (PPROM) and to find their relation with adverse neonatal outcomes in PPROM such as low birth weight, Low APGAR score, NICU admission, birth asphyxia, neonatal sepsis and early neonatal death.

The mean age of the women $23.5 \pm 2.36 \mathrm{Yrs}$ ) in our study was lower than that $(28.7 \pm 2.2$ Yrs $)$ observed by Manuck and Varner [14] and $(28.7 \pm 5.1$ Yrs) observed by Toprak et al. [15]. This may be due to early marriage which is still prevalent in our state. Women residing in rural areas during pregnancy have been shown to have a slightly more chance to have preterm delivery. Our results were consistent with the results observed by Chang $\mathrm{HH}$ et al. [16] and Theresia B Temu et al. [17]. This may probably be due to women residing in urban area have easy accessibility to health facilities as compared to rural areas. The mean BMI of women in study group was $23.1 \pm 2.3$ and in control group was $23.8 \pm 3.2$. The difference in the BMI between the two groups was statistically not significant ( $\mathrm{p}$ value 0.2 ). The mean BMI of the women in our study $(23.5 \pm 2.8 \mathrm{~kg} / \mathrm{m} 2)$ was lower than $(26.6 \pm 7.3$ $\mathrm{kg} / \mathrm{m} 2$ ) that reported by Manuck and Varner et al. [14]. The mean gravidity in our study was lower than reported by Toprak et al. [15].

The mean gestational age in our study was $33.8 \pm 2.1$ weeks which was lower than mean gestational age $(35.5 \pm 0.8$ weeks) observed in the study done by Melamed et al. [18]. In study group 84 babies $(64.6 \%)$ required NICU admission for various reasons while in control group 63 babies $(48.5 \%)$ required NICU admission. The difference in the NICU admission between two groups was statistically significant. Our results were comparable with that of B. Dundar et al. [19] they observed that $58 \%$ babies in study group require NICU admission. Requirement of NICU admission was much higher than (30\%) observed by Melamed et al. [18]. This difference could be because of difference in study design, local pediatric practice and relatively small sample size of our study.

Women with PPROM had slightly more WBC counts than without PPROM $(10.92 \pm 3.77$ vs 10.26 \pm 4.36 ). Similarly neutrophilic count was slightly more in women with PPROM. The difference in WBC count and neutrophil count was statistically not 
significant. Similar observation was made by B. Dundar et al. [19]. Similarly mean neutrophilic count $(8.79 \pm 3.77 \times 103 / \mathrm{mm} 3)$ for PPROM in our study was also lower than $(9.94 \pm 3.39 \times 103 / \mathrm{mm} 3)$ reported by Toprak et al. [15], but comparable with the results of B. Dundar et al. [19]. They observed a neutrophilic count of $8.7 \times 103 / \mathrm{mm} 3$. PPROM was also associated with abnormal erythrocyte parameters including anaemia. Our results were consistent with observations made by J. Liu et al. [20] and Obi SN et al. [21]. The mean platelet count $(224.2 \pm 66.43 \times 103 / \mathrm{mm} 3)$ for PPROM in our study was lower than that observed by Toprak et al. [15] $(244.5 \pm 60.0 \times 103 / \mathrm{mm} 3)$ and J.Liu et al. [20] $(233.2 \pm 70 \times 103 / \mathrm{mm} 3)$, but higher than that observed by B. Dundar et al. [19] $(2.17 \times 103 / \mathrm{mm} 3)$. J. Liu et al. [20] in their study observed that that women with PPROM had Platelet count of $233.2 \pm 70 \times 103 / \mathrm{mm} 3$ which was lower than a platelet count of $274.3 \pm 77.6 \times$ $103 / \mathrm{mm} 3$ in women without PPROM. According to them PPROM was associated with abnormal platelet parameters, including thrombocytopenia, decreased PLT and PDW and increased MPV. In our study mean PDW and MPV were significantly more in women with PPROM than in women without PPROM.

Pregnancy is a hypercoagulable state. The sensitive role of platelets in maintaining the balance between prothrombotic tendency and placental development is vital for the continuation of a pregnancy [22]. Increased platelet volume is a direct indicator of increased platelet synthesis. Increased MPV reflects an increase of active platelets in circulation and in platelet aggregation capacity [23]. Platelets with high MPV are accepted as having more granules containing mediators and being more active. Increased MPV is associated with both arterial and venous vascular pathologies. As pregnancy advances, platelet count decreases, with no significant change in MPV[24]. The number and activities of platelets in complicated pregnancies have been evaluated in a large number of studies. Preeclampsia, premature rupture of membranes (PROM), and IUGR are the most commonly studied pregnancy complications. These studies have reported that increased MPV (and therefore increased platelet activity) increases placental platelet aggregation, causing thrombosis and placental deficiency $[25,26]$.

Maconi et al. [27] have found in PLT and MPV between healthy and nonhealthy pregnant women can be helpful in the differential diagnosis and in the management of complicated pregnancies. In our study women with PPROM had thrombocytopenia and PCT, MPV and PDW were significantly higher in women with PPROM than in women without PPROM. MPV levels might be used as an independent, prognostic marker to predict adverse outcome in PPROM.

Technically a positive correlation existed between maternal platelet count and birth weight $(\mathrm{r}=$ 0.014) and APGAR score $(r=0.105)$ of the babies in women with PPROM by using Pearson's correlation coefficient. With increase in maternal platelet count there is increase in birth weight and APGAR score of the babies and vice versa.

A negative correlation existed between maternal PDW and APGAR score $(r=-0.126)$ and birth weight $(r=-0.142)$ of the babies in women with PPROM by using Pearson's correlation coefficient. With increase in maternal PDW there is decrease in APGAR score and birth weight of the babies and vice versa. A negative correlation existed between maternal MPV and APGAR score ( $\mathrm{r}=-0.063)$ and birth weight $(\mathrm{r}$ $=-0.089$ ) of the babies in women with PPROM by using Pearson's correlation coefficient. A negative correlation also existed between maternal PCT and APGAR score $(r=-0.044)$ and birth weight $(r=-0.075)$ of the babies in women with PPROM by using Pearson's correlation coefficient.

There were several limitations to the present study. Present study had a small sample size from single centre due to limitation of time. Our centre being a tertiary care centre it caters high risk women referred from all over the state, so result of our study may not represent general population. Finally, as we measured $\mathrm{CBC}$ of the women at the time of hospitalization for delivery, serial CBC evaluation may modify the results. Further studies with large sample size are required to validate the role of platelet indices in predicting neonatal outcomes in women with PPROM.

\section{CONCLUSION}

This study shows that platelet count decreases while MPV and PDW increases in preterm pregnancy but these changes are more pronounced in PPROM. To conclude, platelet count, MPV and PDW which are simple, economical and rapid to measure, can be used to predict adverse outcome in PPROM.

\section{REFERENCES}

1. American College of Obstetricians and Gynecologists. (2006). American College of Obstetrics and Gynecology Practice Bulletin No. 76: postpartum hemorrhage. Obstet Gynecol, 108, 1039-1048.

2. Cunningham, F.J., Leveno, K.J., Bloom, S.L., Spong, C.Y., Dashe, J.S., Hoffman, B.L.(2014). Preterm labor. Williams Obstetrics Mc Graw Hill Education 24th ed. New York, 829-61.

3. Lee, T., \& Silver, H. (2001). Etiology and epidemiology of preterm premature rupture of the membranes. Clinics in perinatology, 28(4), 721734.

4. Gopalani, S., Krohn, M., Meyn, L., Hitti, J., \& Crombleholme, W. R. (2004). Contemporary management of preterm premature rupture of membranes: determinants of latency and neonatal 
outcome. American

journal

of

perinatology, 21(04), 183-190.

5. Goys, M., Bernabeu, A., García, N.(2013). Premature rupture of membranes before 34 weeks managed expectantly: Maternal and perinatal outcomes in singletons. J Matern Fetal Neonatal Med, 26: 290-293.

6. Liu, L., Johnson, H.L., Cousens, S. (2000). Global, regional, and national causes of child mortality: An updated systematic analysis for 2010 with time trends since, 2000. (Published erratum appears in Lancet 2012; 380: 1308). Lancet 2012; 379: 21512161

7. Juan, P., Stefano, G., Antonella, S., Albana, C. (2011). Platelets in pregnancy. Journal of Prenatal Medicine, 5(4): 90-92

8. Gasparyan, A.Y., Ayvazyan, L., Mikhailidis, D.P., Kitas, G.D. (2011). Mean platelet volume: A link between thrombosis and inflammation? Curr Pharm Des, 17: $47-58$.

9. Aynıglu, O., Isık, H., Sahbaz, A., Harma, M.I., Isık, M., Kokturk, F.(2016). Can plateletcrit be a marker for recurrent pregnancy loss? Clin Appl Thromb Hemost, 22: 447-452.

10. Piazze, J., Gioia, S., Maranghi, L., Anceschi, M.(2006). Mean platelet and red blood cell volume measurements to estimate the severity of hypertension in pregnancy. J Perinat Med, 34: 246-247.

11. Sahbaz, A., Cicekler, H., Aynioglu, O., Isik, H., Ozmen, U. (2016). Comparison of the predictive value of plateletcrit with various other blood parameters in gestational diabetes development. $J$ Obstet Gynaecol, 36: 589-593.

12. Sahbaz, A., Cicekler, H., Aynioglu, O., Isik, H., \& Ozmen, U. (2016). Comparison of the predictive value of plateletcrit with various other blood parameters in gestational diabetes development. Journal of obstetrics and gynaecology, 36(5), 589-593.

13. Ekin, A., Gezer, C., Kulhan, G., Avcı, M. E., \& Taner, C. E. (2015). Can platelet count and mean platelet volume during the first trimester of pregnancy predict preterm premature rupture of membranes?. Journal of Obstetrics and Gynaecology Research, 41(1), 23-28.

14. Manuck, A., Varner, W.(2014). Neonatal and early childhood outcomes following early vs later preterm premature rupture of membranes. Am J Obst Gyn, 3: 308. e1-308.e6.

15. Toprak, E., Yumru, E.(2017). Platelet-tolymphocyte ratio: A new inflammatory marker for the diagnosis of preterm premature rupture of membranes, 18: 122-6.

16. Chang, H. H., Larson, J., Blencowe, H., Spong, C. Y., Howson, C. P., Cairns-Smith, S., ... \& Walani, S. (2013). Preventing preterm births: trends and potential reductions with current interventionsin 39 very high human development index countries. Lancet, 381(9862), 223.

17. Temu, T. B., Masenga, G., Obure, J., Mosha, D., \& Mahande, M. J. (2016). Maternal and obstetric risk factors associated with preterm delivery at a referral hospital in northern-eastern Tanzania. Asian Pacific Journal of Reproduction, 5(5), 365-370.

18. Melamed, N., Klinger, G., Tenenbaum-Gavish, K., Herscovici, T., Linder, N., Hod, M., \& Yogev, Y. (2009). Short-term neonatal outcome in low-risk, spontaneous, singleton, late preterm deliveries. Obstetrics \& Gynecology, 114(2 Part 1), 253-260.

19. Dundar, B., Dincgez Cakmak, B., Ozgen, G., Tasgoz, F. N., Guclu, T., \& Ocakoglu, G. (2018). Platelet indices in preterm premature rupture of membranes and their relation with adverse neonatal outcomes. Journal of Obstetrics and Gynaecology Research, 44(1), 67-73.

20. Liu, J., Feng, Z. C., \& Wu, J. (2010). The incidence rate of premature rupture of membranes and its influence on fetal-neonatal health: A Report from Mainland China. Journal of tropical pediatrics, 56(1), 36-42.

21. Obi, S. N., \& Ozumba, B. C. (2007). Factors associated with domestic violence in south-east Nigeria. Journal of obstetrics and gynaecology, 27(1), 75-78.

22. Sato, Y., Fujiwara, H., \& Konishi, I. (2010). Role of platelets in placentation. Medical molecular morphology, 43(3), 129-133.

23. Braekkan, S. K., Mathiesen, E. B., Njølstad, I., Wilsgaard, T., Størmer, J., \& Hansen, J. B. (2010). Mean platelet volume is a risk factor for venous thromboembolism: the Troms $\varnothing$ study. Journal of Thrombosis and Haemostasis, 8(1), 157-162.

24. Lamparelli, R. D., Baynes, R. D., Atkinson, P., Bezwoda, W. R., \& Mendelow, B. V. (1988). Platelet parameters. Part I. Platelet counts and mean platelet volume in normal and pregnant subjects. South African medical journal= SuidAfrikaanse tydskrif vir geneeskunde, 73(1), 36-39.

25. Kanat- Pektas, M., Yesildager, U., Tuncer, N., Arioz, D. T., Nadirgil- Koken, G., \& Yilmazer, M. (2014). Could mean platelet volume in late first trimester of pregnancy predict intrauterine growth restriction and pre- eclampsia?.Journal of Obstetrics and Gynaecology Research,40(7), 1840-1845.

26. Cekmez, F., Tanju, I. A., Canpolat, F. E., Aydinoz, S., Aydemir, G., Karademir, F., \& Sarici, S. U. (2013). Mean platelet volume in very preterm infants: a predictor of morbidities. Eur Rev Med Pharmacol Sci, 17(1), 134-137.

27. Maconi, M., Cardaropoli, S., \& Cenci, A. M. (2012). Platelet parameters in healthy and pathological pregnancy. Journal of clinical laboratory analysis, 26(1), 41-44. 